AUTHOR CORRECTION

\title{
Author Correction: Distribution of metallic fission-product particles in the cladding liner of spent nuclear fuel
}

Richard A. Clark (D), Michele A. Conroy (D), Timothy G. Lach (D), Edgar C. Buck (D), Kristi L. Pellegrini, Bruce K. McNamara and Jon M. Schwantes (iD

npj Materials Degradation (2020)4:9; https://doi.org/10.1038/s41529-020-0113-2

Correction to: npj Materials Degradation https://doi.org/10.1038/ s41529-019-0107-0, published online 30 January 2020

The original version of this Article omitted acknowledgements to the original sources of Fig. 1c and Fig. 3.

The following has been added to the end of the caption to Fig. 1:

'Fig. 1c reprinted from Journal of Nuclear Materials, 521, Lach, T. $\mathrm{G}$. et al. Fission recoil-induced microstructural evolution of the fuel-cladding interface $[\mathrm{FCl}]$ in high burnup BWR fuel, 120-125, Copyright (2019), with permission from Elsevier.'

The following has been added to the end of the caption to Fig. 3:

'Lower two panels reused from Schwantes, Jon, M. et al. A new non-diffusional gas bubble production route in used nuclear fuel: implications for fission gas release, cladding corrosion, and next generation fuel design. Physical Chemistry Chemical Physics (2020) Reproduced by permission of the PCCP Owner Societies.'
This has been corrected in the PDF and HTML versions of the Article.

Open Access This article is licensed under a Creative Commons Attribution 4.0 International License, which permits use, sharing, adaptation, distribution and reproduction in any medium or format, as long as you give appropriate credit to the original author(s) and the source, provide a link to the Creative Commons license, and indicate if changes were made. The images or other third party material in this article are included in the article's Creative Commons license, unless indicated otherwise in a credit line to the material. If material is not included in the article's Creative Commons license and your intended use is not permitted by statutory regulation or exceeds the permitted use, you will need to obtain permission directly from the copyright holder. To view a copy of this license, visit http://creativecommons. org/licenses/by/4.0/.

(c) The Author(s) 2020 